\title{
Analisis Paparan Kadmium, Besi, Dan Mangan Pada Air Terhadap Gangguan Kulit Pada Masyarakat Desa Ibul Besar Kecamatan Indralaya Selatan Kabupaten Ogan Ilir
}

\author{
Elvi Sunarsih $^{1}$, Achmad Fickry Faisya ${ }^{1}$, Yuanita Windusari ${ }^{1}$, Inoy Trisnaini ${ }^{1}$, Dini Arista ${ }^{1}$, \\ Dwi Septiawati ${ }^{1}$, Yustini Ardila ${ }^{1}$, Imelda Gernauli Purba', Rahmi Garmini \\ ${ }^{1}$ Fakultas Kesehatan Masyarakat Universitas Sriwijaya Palembang \\ Email : elvisunarsih@gmail.com \\ ${ }^{2}$ STIKes Muhammadiyah Palembang
}

Info Artikel:Diterima April 2018 ; Disetujui Agustus 2018 ; Publikasi Oktober 2018

\begin{abstract}
ABSTRAK
Latar Belakang : Air merupakan unsur yang vital dalam kehidupan manusia. Kualitas air bersih menurun akibat tingkah-laku manusia seperti sisa pembuangan pabrik-pabrik kimia/industri, zat-zat detergen, dan asam belerang. Dampak dari terpaparnya air yang mengandung bahan kimia seperti kadmium, besi, dan mangan dapat menimbulkan efek gangguan terhadap kesehatan kronis maupun akut.

Metode : Penelitian ini menggunakan desain studi potong lintang (cross sectional) dengan teknik purposive sampling. Besar sampel yang diambil sebanyak 100 sampel.

Hasil : Hasil penelitian menunjukkan bahwa konsentrasi rata-rata kadmium (Cd) 0,277 mg/L, besi $(\mathrm{Fe}) 0,414$ $\mathrm{mg} / \mathrm{L}$, dan mangan $(\mathrm{Mn})$ 0,213 mg/L masih memenuhi syarat Permenkes Nomor 32 Tahun 2017. Proporsi responden yang mengalami gangguan kulit sebanyak $45 \%$. Variabel lama pajanan dan status alergi mempunyai hubungan yang bermakna ( $p$ value $<0,05$ ), sedangkan variabel konsentrasi $\mathrm{Cd}, \mathrm{Fe}, \mathrm{Mn}$, jenis kelamin, dan umur tidak mempunyai hubungan yang bermakna $(\mathrm{p}>0,05)$ terhadap gangguan kulit.

Simpulan : Konsentrasi rata-rata Cd, Fe, Mn masih memenuhi syarat Permenkes, tetapi belum memenuhi syarat fisik karena memiliki rasa dan berwarna keruh. Gangguan gatal pada kulit disebabkan lama pajanan terhadap air sungai dan status alergi responden. Perlu dilakukan upaya promotif dan edukasi seperti pembuatan pengolah air sederhana skala rumah tangga kepada masyarakat.
\end{abstract}

Keywords : Kadmium; Besi; Mangan; Gangguan Kulit

\section{ABSTRACT}

Title: Analysis of Cadmium, Iron, and Manganese Exposure on Water Cause of Skin Disorders in Desa Ibul Besar Kecamatan Indralaya Selatan Kabupaten Ogan Ilir

Background : Water is a vital element in human life. The quality of clean water decreases because of human behavior such as waste disposal of chemical / industrial plants, detergent, and sulfuric acid. The impact of exposure from water containing chemicals such as cadmium, iron, and manganese that cause chronic and acute health effects.

Methods : This study used cross sectional study design with purposive sampling technique. There are 100 samples. Results : The results showed that the average concentration of cadmium (Cd) $0.277 \mathrm{mg} / \mathrm{L}$, iron (Fe) $0.414 \mathrm{mg} /$ L, and manganese (Mn) $0.213 \mathrm{mg} / \mathrm{L}$ still appropriate quality standard from Permenkes Number 32 Year 2017. The proportion of respondents got skin disorders 45\%. The variables of exposure and allergic status had significant relationship ( $p$ value $<0.05$ ). The concentration variables $\mathrm{Cd}, \mathrm{Fe}, \mathrm{Mn}$, sex, and age had no significant relationship $(p>0.05)$ to skin disorders.

Conclusion: The average concentrations of $\mathrm{Cd}, \mathrm{Fe}, \mathrm{Mn}$ still appropriate quality standard from Permenkes, but they are not appropriate the physical requirements because they have a taste and muddy. Itchy skin disorders are 
caused by exposure of river water and allergic status of respondents. It needs promotive and educational efforts such as making simple household water processing to the community.

Keywords : Cadmium; Iron; Manganese; Skin Disorders

\section{PENDAHULUAN}

Pertumbuhan penduduk di Indonesia yang pesat khususnya di kota-kota besar telah mendorong peningkatan kebutuhan akan perumahan serta pemenuhan kebutuhan akan air bersih. Manusia dapat bertahan hidup beberapa minggu tanpa makan, tetapi hanya dapat bertahan beberapa hari jika tanpa air. Air merupakan suatu sarana utama untuk meningkatkan derajat kesehatan masyarakat, karena air merupakan salah satu media dari berbagai macam penularan penyakit. ${ }^{1}$

Air merupakan unsur yang vital dalam kehidupan manusia. Seseorang tidak dapat bertahan hidup tanpa air, karena itulah air merupakan salah satu penopang hidup bagi manusia. Ketersediaan air di dunia ini begitu melimpah, namun yang dapat dikonsumsi oleh manusia untuk keperluan air minum sangatlah sedikit. Dari total jumlah air yang ada, hanya lima persen saja yang tersedia sebagai air minum, sedangkan sisanya adalah air laut. Selain itu, kecenderungan yang terjadi sekarang ini adalah berkurangnya ketersediaan air bersih itu dari hari ke hari. Semakin meningkatnya populasi, semakin besar pula kebutuhan akan air minum. Sehingga ketersediaan air bersih pun semakin berkurang. Seperti yang disampaikan Jacques Diouf, Direktur Jenderal Organisasi Pangan dan Pertanian Dunia (FAO), saat ini penggunaan air di dunia naik dua kali lipat lebih dibandingkan dengan seabad silam, namun ketersediaannya justru menurun. Akibatnya, terjadi kelangkaan air yang harus ditanggung oleh lebih dari 40 persen penduduk bumi. Kondisi ini akan kian parah menjelang tahun 2025 karena 1,8 miliar orang akan tinggal di kawasan yang mengalami kelangkaan air secara absolut. Kekurangan air telah berdampak negatif terhadap semua sektor, termasuk kesehatan. Tanpa akses air minum yang higienis mengakibatkan 3.800 anak meninggal tiap hari oleh penyakit.

Air bersih adalah air yang memenuhi syarat kesehatan dan harus dimasak terlebih dahulu sebelum diminum. Sedangkan air minum adalah air yang memenuhi syarat kesehatan dan dapat langsung diminum atau layak digunakan sebagai air bersih. Syarat-syarat yang ditentukan sesuai dengan persyaratan kualitas air secara fisika, kimia, dan biologi. Standar kualitas air bersih menurut Peraturan Menteri Kesehatan Keputusan Menteri Kesehatan RI Nomor : 492/Menkes/Per/IV/2010. Air bersih dalam hal ini air tanah terkadang mengalami pencemaran. Pencemaran air tanah umumnya terjadi oleh tingkahlaku manusia seperti oleh zat-zat detergen, asam belerang dan zat-zat kimia sebagai sisa pembuangan pabrik-pabrik kimia/industri. Pencemaran air juga disebabkan oleh pestisida, herbisida, pupuk tanaman yang merupakan unsur-unsur polutan sehingga mutu air berkurang. ${ }^{2}$

Dampak dari terpaparnya air yang mengandung bahan kimia seperti kadmium, besi, dan mangan dalam bentuk kronis maupun akut. Dalam jangka waktu pendek, zat-zat tersebut dapat menimbulkan gangguan sistem pernapasan seperti lemas, batuk, sesak napas, bronchopneumonia, edema paru, dan cyanosis serta methemoglobinemia. Dampak penyimpangan parameter zat kimia adalah dapat meningkatkan reaktivitas pada pembuluh tenggorokan dan sensitivitas pada penderita asma. Zat kimia bersifat racun terutama terhadap paru dengan diawali gangguan pada pernafasan.

Kondisi lingkungan di Desa Ibul Besar sendiri yang dialiri oleh Sungai Ogan serta terdapat pula rawarawa sebenarnya dapat menjadi sumber air bagi masyarakat sekitar, akan tetapi kondisi air yang tidak bersih tentunya tidak dapat dimanfaatkan langsung oleh warga. Sumber air ini dapat digunakan jika warga memiliki keterampilan dalam mengolah sumber air tersebut menjadi sumber air bersih sehingga dapat digunakan oleh warga untuk kebutuhan sehari-hari, termasuk tentang konsumsi. Permasalahan yang timbul yakni sering dijumpai bahwa kulaitas air tanah maupun air sungai yang digunakan masyarakat kurang memenuhi syarat sebagai air minum yang sehat bahkan di beberapa tempat bahkan tidak layak untuk diminum. Air yang layak diminum, mempunyai standar persyaratan tertentu yakni persyaratan fisis, kimiawi dan bakteriologis, dan syarat tersebut merupakan satu kesatuan. Jadi jika ada satu saja parameter yang tidak memenuhi syarat maka air tersebut tidak layak untuk diminum. Pemakaian air minum yang tidak memenuhi standar kualitas tersebut dapat menimbulkan gangguan kesehatan, baik secara langsung dan cepat maupun tidak langsung dan secara perlahan. Kotoran yang terdapat pada air pada umumnya terdiri dari bendabenda besar dan kecil yang terapung, pasir dan lumpur kasar, lumpur halus berbentuk koloid, organisme, mikroorganisme pathogen, zat-zat kimia, dll.

Kondisi ini akan semakin menjadi masalah ketika musim kemarau tiba dimana kuantitas air bersih akan semakin berkurang. Krisis air tersebut menyebabkan terganggunya stabilitas ketersediaan air bagi masyarakat. Dalam rangka penyediaan air bersih pedesaan, sering terdapat kendala misalnya, lokasi pemukiman yang berjauhan, sehingga jika dibangun sistem pengolahan yang terpadu dengan sistem perpipaan membutuhkan biaya yang sangat besar.

Desa Ibul Besar I memiliki luas 900 Ha. Yang terdiri dari 3 Dusun dan 12 RT. Adapun jumlah penduduk di Desa Ibul Besar I sebanyak 2.261 jiwa. Jumlah penduduk laki-laki sebanyak 1.131 jiwa dan 
jumlah penduduk perempuan sebanyak 1.312 jiwa. Dengan jumlah KK sebanyak 456 KK. Sebagian besar warga memiliki mata pencaharian sebagai petani dan nelayan.

Berdasarkan hasil musyawarah desa yang dilakukan oleh Masyarakat Desa Ibul Besar I diketahui bahwa ketersediaan air bersih masih menjadi permasalahan bagi sebagian masyarakat di daerah tersebut. Hal ini terbukti dari observasi yang dilakukan di lapangan memperoleh hasil bahwa masyarakat Desa Ibul Besar I yang telah memiliki akses air bersih ialah sebesar $78,3 \%$, sedangkan sisanya yaitu $21,7 \%$ belum mendapatkan akses air bersih.

\section{MATERI DAN METODE}

Jenis penelitian ini adalah penelitian analitik dengan menggunakan desain studi potong lintang (cross sectional). Lokasi penelitian di Desa Ibul Besar Kecamatan Pemulutan Kabupaten Ogan Ilir. Adapun populasi penelitian ini adalah seluruh masyarakat di Desa Ibul Besar Kecamatan Pemulutan Kabupaten Ogan Ilir. Unit sampling adalah masyarakat dan sampel penelitian adalah masyarakat terpilih yang menggunakan air sungai untuk aktivitas sehari-hari. Sampel akan diambil dengan menggunakan teknik purposive sampling.

Berdasarkan hasil perhitungan diperoleh besar sampel minimal adalah 78,88 dibulatkan menjadi 80 responden. Namun, mempertimbangkan kondisi di lapangan maka untuk menghindari adanya loss to follow up atau sampel drop out, besar sampel minimal akan ditambah sebanyak $20 \%$ yaitu 16 responden. Jadi total sampel minimal yang dibutuhkan dalam penelitian ini adalah 96 responden. Oleh karena itu, dilapangan jumlah sampel yang akan diambil digenapkan sehingga total sampel yang akan diambil menjadi 100 responden.

\section{HASIL PENELITIAN}

Berdasarkan analisis univariat, diketahui sebagian besar responden berjenis kelamin perempuan dengan jumlah sebanyak 52 orang (52\%) dan jumlah responden laki-laki berjumlah 48 orang (48\%). Karakteristik umur responden dengan persentase terbanyak berumur $\geq 44$ tahun yaitu berjumlah 53 orang (53\%). Pekerjaan responden sebagian besar sebagai petani yaitu berjumlah 43 orang (43\%). Responden yang mempunyai status alergi yaitu sebanyak 45 orang dan responden yang tidak mempunyai status alergi sebanyak 55 orang. Lama pajanan responden yang kontak langsung dengan air sungai untuk melakukan aktivitas sehari-hari dengan pajanan $\geq 7$ jam/hari yaitu sebanyak 38 orang dan $<7$ jam/hari terdapat 62 orang.

Hasil analisis konsentrasi kadmium pada air sungai di Desa Ibul Besar I mempunyai nilai rata-rata 0,277 mg/L dengan standar deviasi 0,010. Hasil pengukuran konsentrasi kadmium pada air terendah yaitu $0,017 \mathrm{mg} / \mathrm{L}$ dan yang tertinggi $0,041 \mathrm{mg} / \mathrm{L}$. Hasil analisis konsentrasi besi mempunyai nilai rata-rata
0,414 mg/L dengan standar deviasi 0,141. Hasil pengukuran konsentrasi besi pada air terendah 0,215 $\mathrm{mg} / \mathrm{L}$ dan yang tertinggi $0,535 \mathrm{mg} / \mathrm{L}$. Hasil pengukuran konsentrasi mangan mempunyai nilai rata-rata 0,213 $\mathrm{mg} / \mathrm{L}$ dengan standar deviasi 0,170 . Hasil pengukuran konsentrasi mangan pada air terendah yaitu $0,035 \mathrm{mg} / \mathrm{L}$ dan yang tertinggi $0,440 \mathrm{mg} / \mathrm{L}$.

Gangguan kulit pada responden didapat dari hasil wawancara menggunakan kuesioner dan pemeriksaan fisik dengan tanda-tanda gatal pada kulit responden dalam waktu satu tahun terakhir. Hasil penelitian menunjukkan bahwa proporsi responden yang mengalami gangguan kulit sebanyak 45 orang $(45 \%)$. Keluhan subjektif didapat dari hasil wawancara menggunakan kuesioner untuk melihat keluhan kesehatan seperti mual $4 \%$, muntah $3 \%$, diare $10 \%$, keram otot $65 \%$, tremor $31 \%$, denyut jantung cepat $18 \%$, sakit kepala $54 \%$, pusing $64 \%$, telinga berdenging $17 \%$, cepat lelah $27 \%$, tekanan darah tinggi $27 \%$, serta kulit dan kuku kebiruan $0 \%$ yang responden alami dalam waktu satu tahun terakhir.

Hasil analisis hubungan konsentrasi kadmium, besi, dan mangan terhadap gangguan kulit didapatkan $p$ value $>0,05$ artinya secara statistik tidak ada perbedaan gangguan kulit pada konsentrasi kadmium, besi, dan mangan. Hasil analisis hubungan jenis kelamin terhadap gangguan kulit didapatkan $p$ value $=$ 0,717 artinya secara statistik tidak ada perbedaan gangguan kulit pada perempuan dan laki-laki. Hasil analisis hubungan umur terhadap gangguan kulit didapatkan $p$ value $=0,793$ artinya secara statistik tidak ada perbedaan gangguan kulit pada responden yang berumur $\geq 44$ tahun dan $<44$ tahun.

Hasil analisis hubungan status alergi terhadap gangguan kulit terlihat bahwa responden yang mempunyai status alergi dengan gangguan kulit yaitu $62,2 \%$. Hasil uji chi square didapatkan $p$ value $=0,003$ artinya secara statistik ada perbedaan gangguan kulit pada responden yang mempunyai status alergi dan tidak mempunyai status alergi. Hasil analisis diperoleh $\mathrm{OR}=3,682(1,604-8,450)$ artinya responden yang mempunyai status alergi berisiko 3,682 kali untuk terkena gangguan kulit dibandingkan responden yang tidak mempunyai status alergi.

Hasil analisis hubungan lama pajanan terhadap gangguan kulit terlihat bahwa responden yang mempunyai lama pajanan $\geq 7$ Jam/Hari dengan gangguan kulit yaitu $68,4 \%$ lebih tinggi dibandingkan dengan responden yang mempunyai lama pajanan $<7$ Jam/Hari yaitu 30,6\%. Hasil uji chi square didapatkan $p$ value $=0,001$ artinya secara statistik ada perbedaan gangguan kulit pada responden yang mempunyai lama pajanan $\geq 7 \mathrm{Jam} /$ Hari dan $<7 \mathrm{Jam} /$ Hari. Hasil analisis diperoleh $\mathrm{OR}=4,904(2,051-11,721)$ artinya responden yang mempunyai lama pajanan $\geq 7$ Jam/Hari berisiko 4,904 kali untuk terkena gangguan kulit dibandingkan responden yang mempunyai lama pajanan $<7$ Jam/Hari. 


\section{PEMBAHASAN}

\section{A. Konsentrasi Kadmium (Cd), Besi (Fe), dan} Mangan (Mn) Pada Air

Gambaran konsentrasi kadmium pada air sungai di Desa Ibul Besar I berkisar antara $0,017 \mathrm{mg} / \mathrm{L}$ sampai $0,041 \mathrm{mg} / \mathrm{L}$ dengan rata-rata $0,277 \mathrm{mg} / \mathrm{L}$. Hasil analisis konsentrasi besi berkisar antara $0,215 \mathrm{mg} / \mathrm{L}$ sampai $0,535 \mathrm{mg} / \mathrm{L}$ dengan rata-rata $0,414 \mathrm{mg} / \mathrm{L}$. Hasil pengukuran konsentrasi mangan berkisar antara 0,035 $\mathrm{mg} / \mathrm{L}$ sampai $0,440 \mathrm{mg} / \mathrm{L}$ dengan rata-rata $0,213 \mathrm{mg} / \mathrm{L}$. Hasil uji statistik diperoleh $p$ value $>0,05$ artinya secara statistik tidak ada perbedaan yang signifikan antara konsentrasi kadmium, besi, dan mangan pada air dengan responden yang mengalami gangguan kulit atau yang tidak mengalami gangguan kulit. Berdasarkan Permenkes Nomor 32 Tahun 2017 Tentang Standar Baku Mutu Kesehatan Lingkungan dan Persyaratan Kesehatan Air Untuk Keperluan Higiene Sanitasi, Kolam Renang, Solus Per Aqua, dan Pemandian Umum bahwa syarat maksimum kadar kadmium pada air untuk keperluan higiene sanitasi yaitu $0,005 \mathrm{mg} / \mathrm{L}$, kadar besi yaitu $1 \mathrm{mg} / \mathrm{L}$, dan kadar mangan yaitu $0,5 \mathrm{mg} / \mathrm{L} .{ }^{3}$ Hasil pengukuran dalam penelitian ini menunjukkan bahwa air sungai masih berada di bawah Baku Mutu Lingkungan (BML).

Hasil penelitian risiko pajanan logam berat pada air Sungai Tabatan Provinsi Kalimantan Selatan yang masih digunakan oleh masyarakat sebagai bahan baku air minum padahal beberapa sungai sudah tercemar akibat aktifitas industri. Risiko pajanan dengan menghitung asupan (I), Hazard Indeks (HI) kemudian menyimpulkan perlunya pengendalian terhadap risiko pajanan tersebut. Hasil penelitian menunjukkan hanya logam Mangan (Mn) yang terdeteksi dan melebihi ambang batas, Nilai I pada golongan umur $1-<5$ tahun pada bagian hulu sungai 0,025154 dan bagian hilir sungai 0,066077, sedangkan untuk golongan dewasa bagian hulu 0,012111 dan bagian hilir 0,031815 $\mathrm{mg} / \mathrm{kg}$-hari. Nilai HI hasil perhitungan menunjukkan $\mathrm{HI}<1$ sehingga disimpulkan bahwa tingkat asupan logam Mangan (Mn) dari air sungai masih dibawah dosis referensinya (RfD) yang artinya batas pajanan masih aman. ${ }^{4}$

Pertumbuhan penduduk yang meningkat akan memberikan tekanan besar terhadap jumlah ketersediaan sumber-sumber air. Untuk daerah yang belum mendapatkan pelayanan air bersih dari PDAM umumnya masyarakat menggunakan air tanah (sumur), air sungai, air hujan, dan sumber air lainnya. Permasalahan yang timbul yakni sering dijumpai bahwa kualitas air tanah yang digunakan masyarakat kurang memenuhi syarat sebagai air bersih dan air minum. Berdasarkan penelitian yang dilakukan, di Kelurahan Mekarsari Kota Bekasi, beberapa air tanah mengandung zat besi (Fe) dan Mangan (Mn) yang cukup tinggi, berbau dan berwarna coklat atau kemerahanan, apabila digunakan untuk mandi membuat kulit menjadi kering. ${ }^{5}$

Penelitian yang dilakukan oleh Maigari et.al bahwa sampel air dari bendungan Dadinkowa Timur laut Nigeria memiliki konsentrasi besi $1.86 \mathrm{mg} / \mathrm{L}$, mangan $0.68 \mathrm{mg} / \mathrm{L}$, nikel $0.59 \mathrm{mg} / \mathrm{L}$ dan kobalt $0.42 \mathrm{mg} / \mathrm{L}$ di atas ambang batas. Penilaian risiko kesehatan dilakukan dengan menentukan asupan harian kronis, hazard quotient dan total hazard indeks melalui konsumsi oral untuk orang dewasa dan anakanak yang dapat menimbulkan risiko kesehatan. ${ }^{6}$

Air sungai yang digunakan untuk keperluan sehari-hari oleh masyarakat Desa Ibul Besar I masih belum memenuhi syarat fisik aspek bersih untuk keperluan higiene sanitasi karena air yang digunakan memiliki rasa dan berwarna keruh. Pada saat pengukuran kualitas air berdasarkan syarat kimia aspek air bersih yaitu kadar kadmium, besi dan mangan masih dibawah baku mutu lingkungan atau tidak melebihi syarat maksimum yang dianjurkan. Masyarakat masih menggunakan air sungai untuk keperluan sehari-hari seperti MCK, mencuci, sebagian kecil masyarakat masih menggunakan sebagai bahan baku air minum dan berladang. Meskipun kadar kadmium, besi dan mangan tidak melebihi nilai baku mutu lingkungan, masyarakat terpapar terus-menerus dengan lama pajanan rata-rata 7 jam setiap harinya yang dapat mengiritasi kulit.

\section{B. Gangguan Kulit dan Keluhan Subjektif Pada Responden}

Gangguan kulit pada responden didapat dari hasil wawancara menggunakan kuesioner dan pemeriksaan fisik dengan tanda-tanda gatal pada kulit responden dalam waktu satu tahun terakhir. Hasil penelitian menunjukkan bahwa proporsi responden yang mengalami gangguan kulit sebanyak 45 orang (45\%). Keluhan subjektif didapat dari hasil wawancara menggunakan kuesioner untuk melihat keluhan kesehatan seperti mual $4 \%$, muntah $3 \%$, diare $10 \%$, keram otot $65 \%$, tremor $31 \%$, denyut jantung cepat $18 \%$, sakit kepala $54 \%$, pusing $64 \%$, telinga berdenging $17 \%$, cepat lelah $27 \%$, tekanan darah tinggi $27 \%$, serta kulit dan kuku kebiruan $0 \%$ yang responden alami dalam waktu satu tahun terakhir.

Berdasarkan penelitian Irfandi menunjukkan bahwa kandungan kadmium dan timbal pada air sumur gali di Dusun III Desa Bandar Khalipah Deli Serdang mengakibatkan gangguan kesehatan pada penduduk. Penduduk yang mengalami gangguan kesehatan setelah menggunakan air sumur untuk keperluan MCK sebanyak 58 orang $(63,0 \%)$. Gangguan kesehatan yang dirasakan penduduk meliputi gatal-gatal pada kulit sebanyak 23 orang $(25,0 \%)$, gangguan kulit bersisik dan kering sebanyak 20 orang $(21,7 \%)$, dan gangguan kulit gatal dan bersisik sebanyak 14 orang $(15,2 \%)$. Adapun penduduk yang merasakan gangguan kesehatan tersebut berulang sebanyak 49 orang $(53,3 \%)$. Penduduk yang mengalami gangguan kesehatan berkaitan dengan kandungan $\mathrm{Cd}$ dan $\mathrm{Pb}$ pada air sumur gali yang digunakan untuk keperluan makan dan minum, seperti gangguan kesehatan berupa mual sebanyak 6 orang $(6,5 \%)$, mati/kurang rasa sebanyak 20 orang $(21,7 \%)$, tinja berwarna kehitaman sebanyak 
39 orang $(42,4 \%)$, tulang terasa nyeri dan sulit bergerak sebanyak 1 orang $(1,1 \%)$, nyeri pada daerah pinggang sebanyak 2 orang $(2,2 \%)$ dan tekanan darah meningkat sebanyak 7 orang $(7,6 \%)$. Responden yang mengalami gangguan kesehatan yang berulang sebanyak 45 orang $(48,9 \%)^{7}$

Gangguan berupa kulit bersisik dan kering merupakan salah satu efek akut dari pencemaran $\mathrm{Cd}$ terhadap air tanah. Kulit berbeda dari organ lainnya, karena secara fisik merupakan organ yang sangat tidak homogen. ${ }^{8}$ Efek yang ditimbulkan dari bahan pencemar ke organ kulit juda dapat sangat berbeda. Kelainan yang didapat pada kulit dapat disebabkan oleh kelainan baik dari luar tubuh maupun dalam tubuh. ${ }^{9}$

Gangguan kesehatan dapat terjadi akibat penggunaan air sungai yang mengandung kadmium, besi, dan mangan. Logam ini merupakan logam yang berbahaya dan memberikan efek toksik bagi tubuh yang dapat memberikan efek akut dan efek kronis yang akan membahayakan kesehatan penduduk.

\section{Jenis Kelamin}

Hasil analisis hubungan jenis kelamin terhadap gangguan kulit terlihat bahwa perempuan dengan gangguan kulit yaitu 42,3\% lebih rendah dibandingkan dengan laki-laki yaitu 47,9\%. Hasil uji chi square didapatkan $p$ value $=0,717$ artinya secara statistik tidak ada perbedaan gangguan kulit pada perempuan dan laki-laki.

Kulit perempuan lebih berisiko mendapat penyakit kulit dibandingkan dengan pria. Kulit pria mempunyai hormon yang dominan yaitu androgen yang dapat menyebabkan kulit pria lebih banyak berkeringat dan ditumbuhi lebih banyak bulu, sedangkan kulit wanita lebih tipis daripada kulit pria sehingga lebih rentan terhadap kerusakan kulit. ${ }^{10}$

Dalam hasil penelitian ini kemungkinan terjadi karena masyarakat yang berpartisipasi dalam penelitian ini sebagian besar adalah perempuan sekitar $52 \%$ dari pada laki-laki. Perempuan sebagai jumlah yang paling dominan ini merupakan perempuan yang rata-rata berprofesi sebagai ibu rumah tangga sehingga dapat dengan mudah berpartisipasi sementara laki-laki yang rata-rata berprofesi sebagai petani, pada saat dilakukannya penelitian masih berada di tempat kerja sehingga sulit untuk berpartisipasi.

\section{Umur}

Hasil analisis hubungan umur terhadap gangguan kulit terlihat bahwa responden yang berumur $\geq 44$ tahun dengan gangguan kulit yaitu 47,2\% lebih tinggi dibandingkan dengan responden yang berumur $<44$ tahun yaitu 42,6\%. Hasil uji chi square didapatkan $p$ value $=0,793$ artinya secara statistik tidak ada perbedaan gangguan kulit pada responden yang berumur $\geq 44$ tahun dan $<44$ tahun.

Pada usia tua reaksi terhadap bahan kimia mungkin meningkat tetapi bentuk kelainan kulit berupa kemerahan yang terlihat pada usia tua berkurang.
Produksi hormon-hormon penting seperti testosteron, growth hormone, dan estrogen mulai menurun, padahal hormon-hormon tersebut berpengaruh terhadap kesehatan kulit. ${ }^{11}$ Kondisi kulit mengalami proses penuaan mulai dari usia 40 tahun. Pada usia tersebut, sel kulit lebih sulit menjaga kelembabannya karena menipisnya lapisan basal. Selain itu produksi sebum juga menurun tajam, sehingga banyak sel mati yang menumpuk karena pergantian sel menurun. ${ }^{12}$

Komponen-komponen tertentu dari kulit juga jadi berkurang seiring bertambahnya usia. Kulit yang lebih tua juga lebih rentan terhadap alergi, sensitifitas, dan iritasi bila dibandingkan dengan kulit yang lebih muda karena sistem imunitas yang melemah. Melemahnya sistem imunitas pada usia tua disebabkan oleh pengecilan kelenjar Timus. Pemeriksaan anatomis menunjukkan bahwa ukuran maksimal kelenjar Timus terdapat pada usia pubertas, sesudahnya akan mengalami proses pengecilan. Konsekuensinya kemampuan kelenjar Timus untuk mendewasakan sel $\mathrm{T}$ berkurang. Akibat berkurangnya pendewasaan sel $\mathrm{T}$ maka ekspresi molekul adesi sel dan pelepasan sitokin yang menjadi penyebab munculnya peradangan. ${ }^{13}$

\section{E. Status Alergi}

Hasil analisis hubungan status alergi terhadap gangguan kulit terlihat bahwa responden yang mempunyai status alergi dengan gangguan kulit yaitu 62,2 didapatkan $p$ value $=0,003$ artinya secara statistik ada perbedaan gangguan kulit pada responden yang mempunyai status alergi dan tidak mempunyai status alergi. Hasil analisis diperoleh OR $=3,682(1,604-$ $8,450)$ artinya responden yang mempunyai status alergi berisiko 3,682 kali untuk terkena gangguan kulit dibandingkan responden yang tidak mempunyai status alergi.

Reaksi tubuh akibat alergi dari agen iritan adalah dengan membentuk komplek hapten-protein yang merangsang pembentukan antibodi. Selanjutnya akan terjadi penyumbatan pada kelenjar dan saluran sebasea sehingga timbul peradangan lokal. Perlu diketahui bahwa substansi yang sama bisa menimbulkan reaksi iritasi sekaligus reaksi alergi, biasanya konsentrasi yang lebih tinggi akan menyebabkan reaksi iritasi. ${ }^{14}$

\section{F. Lama Pajanan}

Hasil analisis hubungan lama pajanan terhadap gangguan kulit terlihat bahwa responden yang mempunyai lama pajanan $\geq 7$ Jam/Hari dengan gangguan kulit yaitu 68,4\%. Hasil uji chi square didapatkan $p$ value $=0,001$ artinya secara statistik ada perbedaan gangguan kulit pada responden yang mempunyai lama pajanan $\geq 7$ Jam/Hari dan $<7$ $\mathrm{Jam} /$ Hari. Hasil analisis diperoleh OR = 4,904 (2,051$11,721)$ artinya responden yang mempunyai lama pajanan $\geq 7 \mathrm{Jam} /$ Hari berisiko 4,904 kali untuk terkena gangguan kulit dibandingkan responden yang mempunyai lama pajanan $<7$ Jam/Hari.

Kelompok risiko tinggi (high risk group) terkena suatu penyakit adalah sub kelompok dari suatu 
kelompok yang mempunyai risiko lebih besar serta dampaknya lebih besar atau lebih berat apabila terpajan (exposed) zat penyebab penyakit yang lebih besar, rentang waktu atau lamanya suatu kelompok menetap disuatu tempat mengakibatkan lebih memilki risiko yang tinggi akan dampak dari suatu penyakit. ${ }^{15}$

Meskipun lama pajanan tidak memengaruhi kejadian gangguan kulit pada masyarakat Desa Ibul Besar I diharapkan masyarakat untuk tidak menggunakan air sungai dengan cara membuat tempat penampungan tersendiri atau mengolah air secara sederhana.

\section{SIMPULAN}

Konsentrasi rata-rata kadmium (Cd) 0,027 $\mathrm{mg} / \mathrm{L}$, besi (Fe) 0,414 mg/L, dan mangan (Mn) 0,213 $\mathrm{mg} / \mathrm{L}$ masih memenuhi syarat baku dari Permenkes Nomor 32 Tahun 2017 tentang standar baku mutu kesehatan lingkungan dan persyaratan kesehatan air untuk keperluan higiene sanitasi, kolam renang, solus per aqua, dan pemandian umum. Karakteristik responden berjenis kelamin perempuan $52 \%$, rata- rata umur responden 44 tahun dan pekerjaan responden sebagian besar sebagai petani. Responden yang mempunyai status alergi yaitu sebanyak 45\%. Lama pajanan responden yang kontak langsung dengan air sungai untuk melakukan aktivitas sehari-hari memiliki rata-rata lama pajanan $7 \mathrm{jam} / \mathrm{hari}$. Gangguan kulit pada responden didapat dari hasil wawancara menggunakan kuesioner dan pemeriksaan fisik dengan tanda-tanda gatal pada kulit responden dalam waktu satu tahun terakhir. Proporsi responden yang mengalami gangguan kulit sebanyak 45\%. Variabel lama pajanan dan status alergi secara statistik menunjukkan adanya hubungan yang bermakna terhadap gangguan kulit, sedangkan variabel konsentrasi $\mathrm{Cd}, \mathrm{Fe}, \mathrm{Mn}$, jenis kelamin, dan umur secara statistik menunjukkan tidak adanya hubungan yang bermakna terhadap gangguan kulit.

\section{SARAN}

Kementerian Lingkungan Hidup dan Pemerintah daerah (BPLHD) disarankan untuk melakukan review dan pengembangan peraturan terhadap standar $\mathrm{Cd}, \mathrm{Fe}$, dan Mn pada air bersih yang digunakan untuk keperluan masyarakat sehari-hari dan melakukan monitoring tahunan serta berusaha mengurangi pencemar air di lingkungan. Melakukan upaya promotif dan edukasi seperti pembuatan pengolah air sederhana skala rumah tangga.

\section{DAFTAR PUSTAKA}

1. Kusnaedi. Mengolah Air Gambut dan Air Kotor Untuk Air Minum. Penerbit Swadaya. Jakarta; 2004.

2. Supardi, I. Lingkungan Hidup dan Kelestariannya. Penerbit PT. Alumni Bandung; 2003.

3. Peraturan Kemenkes RI. Nomor 32 tentang Standar Baku Mutu Kesehatan Lingkungan dan Persyaratan Kesehatan Air Untuk KeperluanHigiene Sanitasi,
Kolam Renang, Solus Per Aqua, dan Pemandian Umum. Jakarta; 2017.

4. Pahruddin, Muhammad. Risiko Pajanan Logam Berat Pada Air Sungai. Jurnal Kesehatan Lingkungan, 2017, 14(2).

5. Febrina, Laila. Studi Penurunan Kadar Besi (Fe) dan Mangan (Mn) Dalam Air Tanah Menggunakan Saringan Keramik. Volume 7 No.1 Januari 2015 ISSN : $2085 \quad-\quad 1669 . \quad$ DOI: 10.24853/jurtek.7.1.35-44.

6. Maigari et al. Health Risk Assessment for Exposure to Some Selected Heavy Metals via Drinking Water from Dadinkowa Dam and River Gombe Abba in Gombe State, Northeast Nigeria 2016. World Journal of Analytical Chemistry, 2016, 4(1): 1-5.

7. Irfandi, Ahmad, dkk. Analisis Kandungan Kadmium (Cd) dan Timbal (Pb) Pada Air Sumur Gali Penduduk di Sekitar Industri Daur Ulang Aki dan Gangguan Kesehatan Pada Masyarakat Desa Bandar Khalipah Kabupaten Deli Serdang. Sumatera Utara. Jurnal Kesehatan Lingkungan USU, 2014, 3(2).

8. Sudarmaji. Toksikologi Logam Berat B3 dan Dampaknya Terhadap Kesehatan. Jurnal Kesehatan Lingkungan, 2006, 2(2): 129 -142.

9. Soemirat, J. Kesehatan Lingkungan. Gadjah Mada University Press. Yogyakarta; 2007.

10. Suryani, F. Faktor-faktor yang berhubungan dengan dermatitis kontak pada pekerja bagian processing dan filling PT Cosmas Indonesia. Tangerang Selatan; 2011.

11. Taylor JS, Sood A, Amado A. Irritant contact dermatitis. Dalam: Fitzpatricks et al, editors. Dermatology in general medicine vol.1 7th ed. New York: Mc Graw Hill Medical;2008.p.395-401.

12. HSE. The Prevalence of Occupational Dermatitis among Work in The Printing Industry and Your Skin. hsebooks.co.uk; 2000.

13. Indrawan, Irvan Ade et al. Faktor-Faktor Yang Berhubungan Dengan Kejadian Dermatitis Kontak Iritan Pada Pekerja Bagian Premix Di PT. X Cirebon. Jurnal Kesehatan Masyarakat (e-Journal), 2014, 2(2).

14. Azhar, Khadijah et al. Hubungan Proses Kerja Dengan Kejadian Dermatitis Kontak Iritan Pada Petani Rumput Laut di Kabupaten Bantaeng Sulawesi Selatan. Jurnal Ekologi Kesehatan, 2011, 10(1): $1-9$.

15. Achmadi. Dasar-dasar Penyakit Berbasis Lingkungan. Jakara: Universitas Indonesia Press; 2010. 